\title{
POLITIK PLURALISME HUKUM DALAM HUKUM UNDANG-UNDANG KEKUASAAN KEHAKIMAN : KAJIAN TERHADAP PENGAKUAN HUKUM TIDAK TERTULIS DALAM UNDANG-UNDANG NOMOR 48 TAHUN 2009 TENTANG KEKUASAAN KEHAKIMAN
}

\author{
Mohammad Jamin \\ Fakultas Hukum Universitas Sebelas Maret \\ E-mail: yamin_mh@yahoo.com
}

\begin{abstract}
It is empirical fact in Indonesia not only has written law which imposed by state power ( state law). Beside written law there is also unwritten law which often called the non state law. Political of law to uniting as one political unity and enforce the legal sentralism has disregarded the fact of legal pluralism ( the political of ignorance). Political of law of the Judicial Power Code which imposed during the time does not clearly arrange the state recognation to unwritten law, even unwritten law is recognnized, but still very sumir and floating. Although Code No. 48/2009 about Judicial Power adopt the politics of legal pluralism and recognizes the existence unwritten law, but it is still sham (weak legal pluralism), causing that in fact predominate the state law still happened and unwritten law only becoming complement to state law. Political forwards legal pluralism in Judicial Power Code ideally is not made conditional. The political legal pluralism of Judicial Power Code must to adopt strong legal pluralism, so can accommodate pluralism in society.
\end{abstract}

Key Words : Legal Pluralism, Judicial Power, Unwritten Law.

\section{A. Pendahuluan}

Sejak awal kemerdekaan hingga saat ini, kekuasaan kehakiman di Indonesia mengalami perkembangan yang cukup dinamis, ditandai dengan perubahan perundang-undangan yang mengaturnya, hingga perkembangan lembaga-lembaga peradilan yang kian kompleks. Kekuasaan kehakiman merupakan kekuasaan yang dijalankan secara independen, profesional, untuk mewujudkan cita hukum (rechts idee) sebagaimana dikemukakan Gustav Radbruch yaitu bergerak untuk menciptakan keadilan (gerechtmatigheid/justice), kemanfaatan (doelmatigheid/utility), dan kepastian hukum (rechtmatigheid/legal certainty) (I Nyoman Nurjaya. 2008 : 3). Kekuasaan kehakiman adalah kekuasaan yang merdeka, oleh karena itu untuk mewujudkan kekuasaan kehakiman yang mandiri dipandang perlu adanya pemisahan yang jelas antar fungsi-fungsi yudikatif dari eksekutif. Dalam konteks ini, kekuasaan kehakiman perlu diatur secara cermat dan sistematis dalam suatu perundang-undangan khusus (exceptional acts).

Dalam UUD 1945 sebelum diamandemen, kekuasaan kehakiman diatur dalam 2 (dua) pasal yaitu Pasal 24 dan Pasal 25. Perubahan Undang-Undang
Dasar Negara Republik Indonesia Tahun 1945 telah membawa perubahan dalam kehidupan ketatanegaraan, khususnya dalam pelaksanaan kekuasaan kehakiman. Hasil Amandemen ke tiga dan ke empat UUD 1945 tentang kekuasaan kehakiman diatur lebih lengkap dalam 5 (lima) Pasal yaitu Pasal 24, 24A, 24B, 24C dan 25.

Secara historis, sejak kemerdekaan Indonesia telah berlaku berbagai undang-undang kekuasaan kehakiman. Berdasarkan pasal II aturan Peralihan Undang-Undang Dasar 1945, maka susunan pengadilan masih menggunakan seperti yang diatur di dalam Undang-Undang N0. 34 Tahun 1942 (yang merupakan peninggalan pemerintahan Jepang). Kemudian terbitlah UndangUndang No. 7 tahun 1947 tentang Susunan Kekuasaan Mahkamah Agung dan Kejaksaaan Agung yang mulai berlaku pada tanggal 3 Maret 1947. Pada tahun 1948, Undang-Undang No. 7 tahun 1947 diganti dengan Undang-Undang No. 19 tahun 1948 tentang Kekuasaan Kehakiman yang dalam pasal 50 ayat 1 memberi penegasan bahwa Mahkamah Agung Indonesia ialah pengadilan federal tertinggi.

Setelah kembali ke UndangUndang Dasar 1945 maka pada tahun 1965 dibuat UndangUndang yang 
mencabut Undang-Undang No. 19 tahun 1948 dengan Undang-Undang No. 19 Tahun 1964 (Lembaran Negara Tahun 1964 Nomor 107) tentang KetentuanKetentuan Pokok Kekuasaan Kehakiman. Dalam perkembangannya, di era Orde Baru karena dalam praktek pelaksanaannya Undang-Undang No. 19 Tahun 1964 telah menyimpang dari Undang-Undang Dasar 1945, antara lain pada pasal 19 yang memberikan wewenang kepada presiden untuk dalam "beberapa hal dapat turun atau campur tangan dalam soal pengadilan", serta dalam rangka pemurnian pelaksanaan Undang-Undang Dasar 1945, maka undang-undang tersebut dicabut dan digantikan oleh Undang-Undang No. 14 Tahun 1970 tentang Ketentuan-Ketentuan Pokok Kekuasaan Kehakiman. Setelah dimulainya Era Reformasi UU No. 14 Tahun 1970 mengalami perubahan dengan berlakunya UU Nomor 35 Tahun 1999 TentangPerubahan Atas Undang-Undang Nomor 14 Tahun 1970 Tentang Ketentuan Pokok Kekuasaan Kehakiman.

Selanjutnya UU 14 Tahun 1970 jo. UU No. 35 Tahun 1999 diganti oleh UU No. 4 Tahun 2004 tentang Kekuasaan Kehakiman, dan yang terakhir UU ini diganti oleh UU No. 48 Tahun 2009 tentang Kekuasaan Kehakiman. Dari rentang berlakunya semua undang-undang kekuasaan kehakiman, UU No. 4 Tahun 2004 memiliki "usia" paling pendek. Mengenai alasan digantinya UU No. 4 Tahun 2004 dapat diketahui dalam Penjelasan Umum UU No. 48 Tahun 2009 tentang Kekuasaan Kehakiman. Pada dasarnya Undang-Undang Nomor 4 Tahun 2004 tentang Kekuasaan Kehakiman telah sesuai dengan perubahan Undang-Undang Dasar Negara Republik Indonesia Tahun 1945 di atas, namun substansi UndangUndang tersebut belum mengatur secara komprehensif tentang penyelenggaraan kekuasaan kehakiman, yang merupakan kekuasaan yang merdeka yang dilakukan oleh sebuah Mahkamah Agung dan badan peradilan yang berada di bawahnya dalam lingkungan peradilan umum, lingkungan peradilan agama, lingkungan peradilan militer, lingkungan peradilan tata usaha negara, dan oleh sebuah Mahkamah Konstitusi, untuk menyelenggarakan peradilan guna menegakkan hukum dan keadilan. Selain pengaturan secara komprehensif, Undang-Undang ini (UU No 48 Tahun 2009) juga untuk memenuhi putusan Mahkamah Konstitusi Nomor 005/PUU/2006, yang salah satu amarnya telah membatalkan Pasal 34 UndangUndang Nomor 4 Tahun 2004 tentang Kekuasaan Kehakiman. Putusan Mahkamah Konstitusi tersebut juga telah membatalkan ketentuan yang terkait dengan pengawasan hakim dalam Undang-Undang Nomor 22 Tahun 2004 tentang Komisi Yudisial.

Secara teoritis perundangundangan merupakan penjabaran politik hukum suatu negara yang mengatur materi sesuai undang-undang yang bersangkutan. Undang-undang kekuasaan kehakiman dengan demikian adalah juga merupakan implementasi politik hukum di bidang kekuasaan kehakiman di Indonesia.

Adalah suatu fakta sosiologis bahwa di Indonesia berlaku bukan hanya hukum undang-undang yang dibuat dan diberlakukan oleh kekuasaan negara (state), yang sering juga disebut sebagai hukum tertulis, state law (http://soetandyo.wordpress.com/2010/08/ 19/masalah-pluralisme-dalam-sistemhukum-nasional/,12/8/2011), hukum formal, atau hukum positip. Di samping hukum tertulis terdapat juga hukum tidak tertulis yang sering juga disebut non state law, living law (Eugen Erlich mengartikannya sebagai hukum yang hidup atau das lebend Recht, the living law yang dianut rakyat dengan segala keyakinannya, (Sutandyo Wignjosoebroto. 2006 : 1), yang dapat disamakan dengan hukum adat (adat recht) (Iman Sudiyat. 1991 : 1), customary law (I Nyoman Nurjaya, 2006 : 8), atau indigenous law (Marc Galanter. 1981 : 175). Hukum negara (state law) bukan satu-satunya wujud hukum yang berlaku dalam masyarakat.

Pengalaman pemerintah kolonial Hindia Belanda untuk menyandingkan hukum yang diberi sanksi negara dengan hukum adat yang dianut rakyat lewat kebijakan dualisme, yang sedikit banyak boleh dibilang "sukses", justru tak diteruskan di era pemerintahan Republik Indonesia. Sekalipun perlu diingat bahwa Pemerintah Hindia Belanda tetap menganggap hukum adat tidak setaraf dengan hokum Eropa yang mempunyai posisi superior atau lebih bagus dan lebih tinggi dari derajadnya daripada hukum 
adat (Mahadi. 1991 : 102-103). Dualisme yang mengakui koeksistensi riil antara hukum Barat dan the people's living law, dan pluralisme yang melihat secara riil banyaknya macam ragam hukum yang sama-sama signifikan dalam kehidupan nasional ini (Marc Galanter. 1981 : 1-47), ternyata tidak dipertimbangkan oleh para pemuka Republik. Cita-cita nasional untuk "menyatukan" Indonesia sebagai satu kesatuan politik dan di bawah kesatuan pemerintahan yang berhukum tunggal telah mengabaikan (the political of ignorance) (I Nyoman Nurjaya, 2006 : 2) fakta kemajemukan hukum yang berlaku dalam masyarakat (Bernadinus Steni. 2008). Alih-alih menyadari dan mempertimbangkan ulang kebijakan yang ada, justru kebijakan unifikasi hukum itulah yang terus saja dikukuhi (Soetandyo Wignjosoebroto. 2008: 237-252).

Sejalan dengan itu, keberadaan dan keberlakuan hukum tidak tertulis dalam konstelasi hukum yang sekarang berlaku menjadi penting untuk dikaji karena adanya kecenderungan sejak hukum itu memasuki era hukum tertulis, yang menjadi salah satu ciri hukum modern, panggung hukum pun berubah menjadi panggung hukum tertulis. Lebih daripada itu, hukum tertulis ini bergandengan tangan dengan dominasi negara modern, yang muncul pada abad ke-18. Sejak saat itu, semua institusi, termasuk hukum, didominasi oleh negara. Terjadilah hegemoni hukum negara, mulai dari pengadilan negeri, pengadilan tinggi dan seterusnya (Bradford W. Morse \& Gordon R. Woodman (eds), 1987: 101120).

Kemungkinan hubungan hukum negara dengan hukum rakyat sebagai berikut (Satjipto Rahardjo, 1995: 12-13).

Pertama, negara penjajah sama sekali menolak hukum rakyat atau adat setempat. Dalam keadaan yang demikian itu kedua sistem normatif berdiri dan bekerja sendiri-sendiri, tanpa ada interaksi satu sama lain sama sekali. Kedua, adalah model kerjasama. Ada berbagai bentuk atau kemungkinan (option) yang dapat dimasukkan ke dalam model ini. Pertama, masingmasing sistem beroperasi sendiri-sendiri, tetapi secara formal sebetulnya ada hubungan antara keduanya, yaitu dalam bentuk (garis batas) yang jelas memisahkan yurisdiksi masingmasing. Suatu mekanisme yang dapat dilakukan adalah dengan membuat perjanjian internasional (treaty). Kemungkinan kedua adalah melalui pencaplokan (incorporation). pihak yang dominan dapat memilih untuk mencaplok bagian-bagian dari hukum setempat atau seluruhnya yang tidak bertentangan dengan sistem yang dimilikinya. Kemungkinan lain berupa langkah yang langsung, yaitu berdasarkan pengakuan tentang patutnya dibiarkan hukum setempat untuk tetap bekerja mengatur masyarakatnya sendiri, tetapi dengan cara pengadministrasian yang dijalankan oleh pengadilan yang didirikan oleh pihak yang dominan. Sedangkan model ketiga adalah yang sama sekali menolak keabsahan dari hukum setempat. Ini didasarkan pada berbagai kualifikasi terhadap hukum asli, seperti "primitif" dan "tidak beradab".

Pengutamaan dan konsentrasi pada hukum negara merupakan hasil suatu perkembangan yang panjang yang memuncak pada munculnya negara modern dan negara konstitusional. Negara modern adalah suatu perkembangan politik yang luar biasa yang meminggirkan susunan masyarakat yang sebelumnya lebih bersifat majemuk. Hukum negara sebagai satu-satunya yang harus diberlakukan dan dengan demikian melihat hukum nasional berlaku absolut di seluruh wilayah negara (Widodo Dwi Putro. 2009 : 12). Penglihatan mengenai hukum nasional demikian itu membawa kita kepada paham sentralisme hukum (legal centralism). Sebagaimana ditulis Satjipto Raharjo :

"Sentralisme hukum, pertamatama melihat hukum itu sebagai hukum negara (state law) dan tidak lain daripada itu. Di luar itu tidak ada hukum lain. Kalau toh 
ada yang lain, maka kehadirannya mendapatkan legitimasinya dari hukum negara tersebut. Pandangan seperti itu dianut oleh sistem hukum Hindia Belanda yang berlaku di Indonesia sebelum kemerdekaan. Kata-kata yang terkenal dari Pasal 15 "Algemeene Bepalingen van Wetgeving" berbunyi "...geeft gewoonte geen recht dan alleen wanneer de wet daaro veraiist" (Satjipto Rahardjo, 1995 : 1).

Sejalan dengan faham sentralisme hukum, maka hukum bukan lagi dikonsepsikan sebagai asas-asas moral metayuridis yang abstrak tentang hakekat keadilan, melainkan ius yang telah mengalami positivisasi sebagai lege atau lex. Sebagai konsekuensinya berkembang faham positivisme yang melihat hukum hanyalah semata-mata undang-undang legal formal yang berlaku secara positip (Adi Sulistiyono, 2004 : 8). Menurut Theo Huijbers prinisp-prinsip dasar dari positivisme adalah :

"Pertama, suatu tatanan hukum negara berlaku bukan karena mempunyai dasar kehidupan dalam kehidupan sosial (menurut Comte dan Spencer) bukan juga karena bersumber pada jiwa bangsa (menurut Savigny), dan juga bukan karena dasar-dasar hukum alam, melainkan karena mendapat bentuk positifnya dari instansi yang berwenang; Kedua, hukum semata-mata harus dipandang dalam bentuk formalnya; ketiga, isi hukum (material) diakui ada, tetapi bukan bahan ilmu hukum karena dapat merusak kebenaran ilmiah ilmu hukum" (Theo Huijbers. 1982: 129).

Faham atau paradigma positivisme (H.R. Otje Salman dan Anton F. Susanto. 2004: 79-80) yang membabibuta ini yang menurut Satjipto Rahardjo menjadi salah satu penyebab tidak dapat berfungsinya hukum untuk melayani manusia dan justru sebaliknya manusia menjadi pelayan hukum. Kondisi ini yang kemudian menyebabkan pengadilan dan keputusan-keputusan hakim hanya melahirkan apa yang disebut formal justice dan bukan substansial justice. Paradigma positivisme kurang mendukung pemenuhan keadilan substansial (C. Maya Indah S.,2010: 115).

Selanjutnya dikatakan oleh Satjipto Raharjo bahwa hukum itu tidak ada untuk dirinya sendiri, melainkan untuk sesuatu yang lebih luas dan lebih besar. Maka setiap kali ada masalah dalam dan dengan hukum, hukumlah yang harus ditinjau dan diperbaiki dan bukan manusia yang dipaksa-paksa untuk dimasukan ke dalam skema hukum (tertulis) (Satjipto Rahardjo. 2004: 2).

Hakim sebagai pelaksana kekuasaan kehakiman mempunyai fungsi memberikan keputusan terhadap perkara yang dihadapkan padanya untuk diadili. Namun, ketika dihadapkan pada kasus yang belum diatur dalam peraturan perundang-undangan, hakim wajib mengisi kekosongan hukum tersebut dengan menggali, memahami nilai-nilai hukum, dan rasa keadilan yang hidup dalam masyarakat. Hakim bukanlah mulut undang-undang atau hukum positip. Walaupun demikian apabila hakim dihadapkan pada pilihan antara ketentuan hukum tertulis dengan hukum tidak tertulis, hakim harus mengutamakan atau mendahulukan hukum tertulis. Namun penerapan ini harus memperhatikan halhal berikut : a. Mengutamakan atau mendahulukan hukum tertulis apabila diketahui atau secara rasional dipahami bahwa ketentuan hukum tertulis merupakan pembharauan terhadap hukum tidak terulis atau terjadi transformasi ketentuan hukum tidak tertulis menjadi hukum tertulis. b. Mengutamakan atau mendahulukan hukum tidak tertulis dilakukan apabila ketentuan hukum tidak tertulis merupakan suatu yang tumbuh, kemudian sebagai koreksi atau penafsiran terhadap suatu ketentuan hukum tertulis. Koreksi merupakan kenyataan hukum yang hidup dalam masyarakat dan dapat terjadi karena hukum tertulis telah using atau ada kekosongan hukum tertentu dalam ketentuan hukum tertulis ( M. Hatta Ali. 2007 : 88-89).

Kritik yang diberikan terhadap pengadilan dan hakim di Indonesia yang menganut sistem civil law adalah putusanputusan yang konservatif dan sangat 
legalistik. Secara teori para hakim di negara dengsn sistem civil law lebih dikenal sebagai juru bicara undang-undang (speakers of law), mengenai hal ini bandingkan dengan pendapat Richard A. Posner mengenai the judge as occasional legislator ( Richard A. Posner, 2010:7992), dan karena itu jarang ditemukan pertimbangan-pertimbangan hukum hakim yang keluar dari perspektif legalistik; kaya dengan penjelasan-penjelasan sosial yang luas dan mendalam (Amzulian Rifai, et.all. 2010: 59-61). Dalam hal ini timbul permasalahan, yang pertama, bagaimanakah politik hukum yang dianut oleh pembentuk Undang-Undang Nomor 48 tahun 2009 tentang Kekuasaan Kehakiman dalam mengatur pengakuan terhadap hukum tidak tertulis?, yang kedua, bagaimana idealitas politik pluralisme hukum yang seharusnya dikembangkan dalam sistem kekuasaan kehakiman di Indonesia dalam rangka membangun lembaga peradilan yang ideal ?

\section{B. Politik Hukum Sebagai Pemandu Pembangunan Hukum}

Banyak definisi tentang politik hukum dijumpai dalam referensi ilmu hukum. Imam Syaukani dan A. Ahsin Thohari (2008 : 18) membagi definisi politik hukum yang dikemukakan beberapa pakar menjadi dua kategori yaitu perspektif etimologis dan terminologis.

Dalam perspektif etimologis politik hukum merupakan terjemahan daribahasa Belanda, rechtspolitiek. Recht dalam bahasa Indonesia berarti hukum, sementara kata hukum berasal dari bahasa Arab hukm yang berarti putusan (judgement), ketetapan (provision), perintah (command), dan pengertian lainnya. Sementara kata politiek mengandung arti beleid, yaitu kebijakan (policy). Politik, dalam penelusuran beberapa literatur berasal dari bahasa Yunani "Подıєıкá" (politika) yang berarti hubungan yang terjadi antar individu (anggota masyarakat) dalam suatu negara. Dalam hubungan (interaksi) yang resiprokal tersebut, terjadi kesepakatan-kesepakatan terhadap suatu keputusan atau kebijakan yang bersifat kolektif. Dengan demikian, secara etimologis, politik hukum adalah kebijakankebijakan yang direncanakan dan dilaksanakan dalam bidanghukum, termasuk pengambilan keputusan-keputusan hukum yang bersifat kolektif.

Dalam Kamus Besar Bahasa Indonesia (KBBI), politik hukum didefinisikan sebagai rangkaian konsep dan asas yang menjadi garis besar dan dasar rencana dalam pelaksanaan suatu pekerjaan, kepemimpinan, dan cara bertindak. Definisi dari KBBI tersebut lebih melihat politik hukum sebagai blueprint terhadap sekalian kebijakan yang akan diambil dalam rangka penegakan hukum pada segenap dimensi kehidupan masyarakat. Dengan demikian, politik hukum merupakan patronase bagi stakeholder dalam melaksanakan tugas, fungsi, dan kewenangannya di bidang hukum.

$$
\text { Dalam perspektif }
$$

terminologis, beberapa pengertian yang diberikan oleh para pemikir yang mendalami kajian politik hukum sebagai berikut.

Menurut Satjipto Rahardjo
politik hukum adalah aktivitas memilih dan cara (metode) yang akan digunakan dalam upaya mencapai suatu tujuan sosial dan hukum tertentu dalam masyarakat (negara). Berdasar pada definisi tersebut, Satjipto Rahardjo mengemukakan beberapa pertanyaan mendasar yang muncul dalam studi politik hukum, yaitu (1) tujuan apa yang ingin dicapai dengan system hukum yang ada (diterapkan); (2) cara-cara (mekanisme) apa yang dianggap paling baik (efektif) untuk mencapai tujuan tersebut; (3) kapan dan bagaimana hukum harus diubah; dan (4) dapatkah dirumuskan suatu pola yang baku dan mapan yang dapat membantu kita memutuskan tujuantujuan serta cara-cara (mekanisme) untuk mencapai tujuan tersebut dengan baik (Satjipto Raharjo. 1991 : 352-353).

Padmo Wahjono berpendapat bahwa politik hukum merupakan kebijakan dasar yang menentukan arah, bentuk, maupun isi (substansi) hukum yang akan dibentuk (Padmo 
Wahyono. 1986 : 160). Definisi ini kemudian diperjelas oleh Padmo Wahyono dalam tulisan lain yang mengatakan bahwa politik hukum adalah kebijakan penyelenggara negara tentang apa yang dijadikan criteria untuk menghukumkan sesuatu yang didalamnya mencakup pembentukan, penerapan dan penegakan hukum (Padmo Wahyono. 1991: 65).

Soedarto menyatakan bahwa politik hukum adalah kebijakan negara melalui institusi-institusi negara yang berwenang untuk menetapkan peraturan yang dikehendaki yang diperkirakan akan dipergunakan untuk mengekspresikan apa yang terkandung dalam masyarakat untuk mencapai apa yang dicita-citakan (Soedarto, 1986 : 151). Abdul Hakim Garuda Nusantara memberikan pengertian politik hukum adalah Kebijakan hukum (legal policy) yang hendak atau telah dilaksanakan secara nasional oleh pemerintah yang dalam implementasinya meliputi: 1) pelaksanaan secara konsisten ketentuan hukum yang telah ada; 2) pembangunan hukum yang berintikan pembaruan atas hukum yang telah ada dan pembuatan hukum-hukum baru; 3) penegasan fungsi lembaga dan pembinaan para anggota penegak hukum; 4) peningkatan kesadaran hukum masyarakat menurut persepsi elit pengambil kebijakan (Abdul Hakim Garuda Nusantara. 1985: tanpa halaman).

Sunaryati Hartono tidak secara eksplisit merumuskan arti politik hukum. Namun dari substansi pengertian yang diberikan ketika menyebut hukum sebagai alat maka secara praktis politik hukum adalah merupakan alat atau sarana dan langkah yang digunakan oleh pemerintah untuk menciptakan sistem hukum nasional yang dapoat dipergunakan untuk mencapai citacita bangsa dan tujuan negara (CFG. Sunaryati Hartono. 1991: 1).

Moh. Mahfud MD mencoba menyederhanakan pengertian politik hukum sebagai arahan atau garis resmi yang dijadikan dasar pijak dan cara untuk membuat dan melaksnakan hukum dam rangka mencapai tujuan bangsa dan negara (Moh. Mahfud MD. 2006: 3). Selanjutnya dikatakan bahwa politik hukum juga sebagai jawaban atas pertanyaan tentang mau diapakan hukum itu dalam perspektif formal kenegaraan guna mencapai tujuan negara. Di dalam pengertian ini pijakan utama politik hukum nasional adalah tujuan negara yang kemudian melahirkan sistem hukum nasional yang harus dibangun dengan pilihan isi dan cara tertentu. Dengan demikian politik hukum mengandung dua sisi yang tak terpisahkan yakni sebagai arahan pembuatan hukum atau legal policy lembaga-lembaga negara dalam pembuatan hukum dan sebagai alat untuk menilai dan mengkritisi apakah huykum yang dibuat sudah sesuai atau tidak dengan kerangka pikir legal policy tersebut untyuk mencapai tujuan negara.

Dalam tulisan lain Moh. Mahfud memberikan pengertian politik hukum secara agak berbeda. Politik hukum adalah legal policy yang akan atau telah dilaksnakan secara nasional oleh pemerintah. Legal policy itu meliputi pertama, pembangunan hukum yang berintikan pembuatan dan pembaruan terhadap materi-materi hukum agar dapat sesuai dengan kebutuhan. Kedua, pelaksanaan ketentuan hukum yang telah ada, termasuk penegasan fungsi lembaga dan pembinaan para penegak hukum. Dari pengertian itu, politik hukum mencakup proses pembuatan dan pelaksanaan hukum, yang dapat menunjukkan sifat dan ke arah mana hukum akan dibangun dan ditegakkan (Moh. Mahfud MD., 2010 : 3).

Berangkat dari pengertian tersebut menurut Moh Mahfud MD. Pembahasan politik hukum untuk mencapai tujuan negara dengan satu sistem hukum nasional mencakup sekurang-kurangnya hal-hal berikut (Moh. Mahfud MD., 2010a : 21):

"(1) tujuan negara atau masyarakat Indonesia yang dididamkan sebagai orientasi politik hukum, termasuk penggalian nilai-nilai dasar tujuan negara sebagai pemadu 
politik hukum; (2) sistem huykum nasional yang diperlukan untuk mencapai tujuan itu serta faktor-faktor yang mempengaruhinya; (3) perencanaan dan kerangka pikir dalam perumusan kebijakan hukum; (4) isi hukum nasional dan faktorfaktor yang mempengaruhinya; (5) pemagaran hukum dengan prolegnas dan judicial review, legislative review dan sebagainya".

\section{Teori Pluralisme Hukum versus Sentralisme Hukum \\ Pluralisme hukum (legal} pluralism) kerap diartikan sebagai keragaman hukum. Menurut John Griffiths, pluralisme hukum adalah hadirnya lebih dari satu aturan hukum dalam sebuah lingkungan sosial (Griffiths, John. 1986 : 1). Pada dasarnya, pluralisme hukum melancarkan kritik terhadap apa yang disebut John Griffiths sebagai ideologi sentralisme hukum (legal centralism). Gagasan pluralisme hukum sebagai sebuah konsep, mulai marak pada dekade 1970an, bersamaaan dengan berseminya ilmu antropologi hukum.

Konsep pluralism hukum dari Grifffiths dapat dibedakan menjadi dua macam yaitu strong legal pluralism dan weak legal pluralism (I Nyoman Nurjaya. 2007 : 14). Suatu kondisi dapat dikatakan strong legal pluralism jika masing-masing sistem hukum yang beragam itu otonom dan eksistensinya tidak tergantung kepada hukum negara. Jika keberadaan pluralisme hukum itu tergantung kepada pengakuan dari hukum negara maka kondisi ini disebut dengan weak pluralism (Kurnia Warman. 2009: 25).

Sentralisme hukum memaknai hukum sebagai "hukum negara" yang berlaku seragam untuk semua orang yang berada di wilayah yurisdiksi negara tersebut. Dengan demikian, hanya ada satu hukum yang diberlakukan dalam suatu negara, yaitu hukum negara. Hukum hanya dapat dibentuk oleh lembaga negara yang ditugaskan secara khusus untuk itu. Manakala tidak ada kesepahaman anatara hukum adat dengan hukum positif milik negara. Negara sebagai pemangku kekuasaan merasa berhak melakukan pemaksaan terhadap dihormatinya hukum positip milik negara sehingga segala persoalan dan perselisihan yang terjadi di dalam wilayah negara RI mau tidak mau harus diselesaikan dengan menggunakan hukum positip milik negara (Anonim. 2009: 32).

Senada dengan itu, sebagai konsekuensinya terjadi kondisi seperti yang dikatakan Anne Griffiths :

"Meskipun ada kaidah-kaidah hukum lain, sentralisme hukum menempatkan hukum negara berada di atas kaidah hukum lainnya, seperti hukum adat, hukum agama, maupun kebiasan-kebiasaan. Kaidahkaidah hukum lain tersebut dianggap memiliki daya ikat yang lebih lemah dan harus tunduk pada hukum negara" (Griffiths, Anne. 2005: 71), (Roger Cotterrel. 2006: 29-44).

Di samping itu, konsekuensi lain adalah terjadi pula konflik kultural yang disebabkan hukum negara yang tertulis dikitab-kitab dan dokumen-dokumen undang-undang tidak selamanya mencerminkan hukum rakyat yang beragam dan plural. Kenyataan seperti itu sesungguhnya mencerminkan pula telah terjadinya apa yang disebut cultural conflict. Isi kaidah yang terkandung dalam hukum negara dengan yang terkandung dalam hukum yang dianut rakyat tidak hanya tak bersesuaian satu sama lain melainkan juga bahkan acap kali bertentangan

http://soetandyo.wordpress.com/2010/ 08/19/masalah-pluralisme-dalamsistem-hukum-nasional/, 12/9/2011).

Dalam perkembangannya, narasi besar tentang pluralisme hukum telah mengalami redefinisi. Pada saat ini pendekatan pluralism hukum yang baru memandang pendekatan lama tidak dapat digunakan lagi. Dalam pendefinisian ulang ini diperlihatkan 
bahwa hukum dari berbagai level; dan penjuru dunia bergerak memasuki wilayah-wilayah yang tanpa batas, dan terjadi persentuhan, interaksi, kontestasi, dan saling adopsi yang kuat di antara hukum internasional, nasional dan lokal. Terciptalah hukum transnational dan transnationalized law (Sulistyowati Irianto. 2007: 3), (Sulistytowati Irianto. 2009: 29). Pluralisme dalam perspektif baru tersebut dapat dirumuskan berikut ini. "...it is mainly understood as the coexistence of state, international and transnational law, and analysis remain limites to the question of wether such transnational connection influence stse law at the national level (Benda-Beckmann F, K. BendaBeckmann and Anne Griffiths. 2005: $6)$.

Hukum tertulis selalu berupaya untuk mengatur hampir segala segi kehidupan manusia dan oleh karena itu hukum terlihat powerfull. Keperkasaan hukum ini ditunjang dengan segala sarana dan prasarana yang memungkinkannya untuk melakukan tindakan pemaksaan secara legal seperti yang dimiliki oleh aparat penegak hukum.

Hukum modern yang ada di Indonesia saat ini pun telah menjadi teknologis dan menjauhkan diri dari wacana moral. Persoalan moral ini merupakan salah satu keterbatasan hukum modern (John Stanton, 2006: tanpa halaman). Antony Allott juga berpendapat serupa, bahwa hukum adalah sesuatu yang berkaitan dengan fakta, hukum ada atau norma itu ada dan tidak berkaitan dengan nilai. Sejak itu hukum memberi peluang terjadinya pengebirian hukum dari kandungan moral, sebab menegakkan atau menjalankan hukum dapat menjadi sinonim dengan menjalankan peraturan semata (Antony Allott. 1980: 58).

$$
\text { Menegakkan }
$$

menjalankan hukum tidak sama persis dengan memproses keadilan, karena hukum modern sudah banyak berubah menjadi institusi formal dan birokratis. Dalam konteks kehidupan yang menggunakan hukum modern, bisa muncul diskrepansi antara keadilan formal atau keadilan peraturan dengan keadilan substansial (Satjipto Rahardjo, 2003: 56,62, 191).

Posisi hukum modern yang esoterik menjadikan ia tidak peka terhadap perubahan dan perkembangan jaman. Hukum tidak bergerak dalam ruang hampa, ia selalu berada dalam tatanan sosial tertentu dan manusia yang hidup (Esmi Warassih. 2005: 3).

$$
\text { Hukum juga harus }
$$

memperhatikan faktor-faktor di luar hukum yang memberikan pengaruh pada perkembangan ilmu dan praktik hukum. Undang-undang bukan segalagalanya karena sebuah undangundang yang dibuat akan selalu berubah substansinya, baik karena perubahan normal maupun cara-cara lain. Sebagaimana dikatakan Oliver Windell Holmes bahwa the life of the law has not been logic but experience (Satjipto Rahardjo. 2000: 18)

Ketertutupan hukum modern menyebabkan ia kesulitan untuk menemukan jawaban atas peristiwa-peristiwa yang tidak ada dalam peraturan tertulis (undangundang), sehingga menyebabkan hukum modern menjadi collapse. Peristiwa-peristiwa yang tidak sesuai norma dari aturan yang telah dibuat menunjukkan bahwa hukum modern yang begitu perkasa pun memiliki keterbatasan kemampuan dalam menjelaskan halhal di luar pakemnya. Oleh sebab itu muncul berbagai kritik yang bertujuan untuk membuat hukum lebih peka pada perubahan dan perkembangan masyarakat. Kritik tidak hanya ditujukan pada keterbatasan kemampuan dalam hal teori, akan tetapi juga berkaitan dengan praktik, terutama ketika hukum itu dioperasikan oleh hakim di pengadilan.

Terhadap keterbatasan kemampuan hukum dalam 
mengatasi persoalan masyarakat yang timbul, menurut Allott, adopsi atau penerimaan mayoritas terhadap hukum baru tidak menjamin kemampuan hukum. Allot memberi dua argumen sebagai jalan keluar, yaitu pendekatan pragmatis sebagai jalan terbaik agar hukum efektif dan pendekatan moral. Selanjutnya ia menekankan penggunaan customary law yang didasarkan pada prinsip konsensus dengan dukungan dari sanksi sosial dinilai akan lebih efektif dalam pelaksanaan hukum (Antony Allott, 1980: 288).

Menghadapi kompleksitas permasalahan yang dihadapi hukum menyelesaikan setiap masalah yang timbul, maka sebaiknya kita mempertanyakan kembali politik hukum dalam undang-undang kekuasaaan kehakiman yang telah dijalankan selama ini. Diperlukan pengkajian kembali terhadap apa yang ingin disebut sebagai "politik sentralisme", yang dipraktekkan selama ini.

Secara umum politik hukum kita sangat menekankan kepada aspek kesatuan atau sentralisme hukum. Sementara itu lambang negara kita dengan bagus mengatakan "Bhinneka Tunggal Ika". Pasal 36 A UUD 1945, yang menegaskan bahwa Lambang Negara ialah Garuda Pancasila dengan semboyan Bhineka Tunggal Ika. Hal ini mempunyai arti penting sendiri, seperti dikatakan Jimly Asshiddiqie, bahwa selama ini hal tersebut belum pernah diatur, sehingga penyebutan Garuda Pancasila sebagai lambang negara, hanya didasarkan atas konvensi tidak tertulis (Jimly Asshiddiqie. 2003: 80). Pengakuan tentang lambang sekaligus penegasan tentang seloka yang terpampang pada lambang Bhineka Tunggal Ika. Menurut Wertheim, Bhineka Tunggal Ika berarti "persatuan dalam perbedaan" merupakan motto resmi Republik Indonesia. Ungkapan ini mengekspresikan suatu keinginan yang kuat, tidak hanya di kalangan pemimpin politik, tetapi juga di kalangan berbagai lapisan penduduk, untuk mencapai kesatuan, meskipun ada karakter yang heterogen pada negara baru yang terbentuk itu. Pada gilirannya, persamaan itu akan mensyaratkan adanya karakteristik budaya yang sama yang mendasari heterogenitas itu (Wartheim WF. 1999: 1).

Dengan ditegaskannya

Bhineka Tunggal Ika dalam konstitusi, maka segala konsekuensi dari penegasan itu juga harus diterima dalam berbagai aspek kehidupan termasuk kehidupan hukum. Pengakuan tentang perlunya ketunggalan hukum (unifikasi) sebagaimana yang dicanangkan dalam berbagai kebijakan pembangunan hukum perlu untuk ditinjau kembali (Abdurrahman. 2006:6). Keberagaman hukum (pluralisme hukum) sepanjang kenyataannya memang demikian, tidak boleh dinafikan begitu saja, apalagi kalau hal ini diartikan sebagai identitas budaya (cultural identity) sebagaimana yang ditegaskan dalam Pasal 28 Ayat (3) Undang-Undang Dasar 1945. Karena itu konstitusi negara RI boleh dikatakan sebagai konstitusi pluralis (Yanis Maladi. 2010 : 456).

$\begin{array}{ccc}\text { Konsep } & \begin{array}{c}\text { "kesatuan" } \\ \text { didukung }\end{array} & \text { dan } \\ \text { oleh }\end{array}$ pendekatan dan pemahaman hukum secara sosiologis, yang tidak menerima sistem atau tatanan hukum sebagai sesuatu yang absolut, tunggal dan monolitik. Optik sosiologis melihat, bahwa tatanan dan tertib masyarakat merupakan suatu totalitas yang terdiri dari berbagai komponen tatanan, kendati pada tingkat kekuatan yang berbeda-beda, ada yang "more order", ada yang "less order". Apabila politik hukum bergerak melawan arus tersebut, maka gangguan dan persoalanpun akan bermunculan. Kita lihat pada perkembangan sistem hukum modern menuju kepada keadaan yang monolitik, yang mengutamakan hukum negara dan meminggirkan wilayah-wilayah yang bukan hukum negara. Pada 
akhirnya hukum negara tidak mampu untuk mengakomodasi sekalian wilayah tersebut dan pada akhirnya harus menyerah dengan memberikan pengakuan terhadap wilayah-wilayah kehidupan di luar yang resmi negara tersebut.

Dalam hubungan dengan hal-hal yang diuraikan di atas, menarik sekali pembahasan Marc Galanter tentang apa yang disebutnya sebagai fenomena "justice in many rooms" yang telah disinggung di muka. Dengan merujuk kepada masalah bekerjanya pengadilan-pengadilan negara, maka penglihatan sosiologis menunjukkan bahwa pengadilan tersebut sebetulnya tidak selalu menjalankan tugasnya secara otoritatif. Tidak sering pengadilan negara menjalankan "fullblown adjudication", yaitu memeriksa dan mengadili secara penuh, melainkan apa yang oleh Knookin dan Kornhauser disebut sebagai "in the shadow of the law". Putusan hakim hanya meligitimasi saja kesepakatan (settlement) yang sebetulnya dicapai oleh para pihak (Marc Galanter. 1981: 155).

Galanter juga mengemukakan kritiknya terhadap kehadiran dan fenomena "sistem hukum nasional" di dunia. Dikatakan oleh Galanter,

"One of the striking features of the modern world has been the emergence of those institutional-intellectual complexes that we identify as national legal systems. Such a system consists of institutions, connected to the state, guided by and propounding a body of normative learning, purporting to encompass and control all the other institutions in the society and subject them to a regime of general rules. These complexes consolidated and displaced the earlier diverse array of normative orderings in society, reducing them to a subordinate and interstitial status" (Marc Galanter. 1981: 163).

Tentang hukum setempat yang pada kita dapat disamakan dengan hukum adat, Galanter menyebutnya indigenous law dan sistemnya disebut indigenous ordering. Galanter juga ingin melihat, bahwa hukum setempat tersebut tidak dapat diserap habis ke dalam sistem hukum nasional begitu saja. Hukum negara tidak dapat menyelesaikan tugasnya secara total dan absolut, dengan mengatur semua masalah secara tuntas, melainkan hanya melakukannya secara sepotong-potong. ".......legal regulation in modern societies, as in others, has a more uneven, patchwork character" (Marc Galanter. 1981: 165).

Untuk merangkum hukum tidak tertulis secara substansial ke dalam sistem hukum nasional, maka kita tidak dapat membangun suatu sistem tatanan yang monolitik, melainkan yang memberi suatu ruangan bagi otonomi pengaturan dan mendorong terciptanya suatu hubungan sinergistis antara hukum negara dan lain-lain penataan, termasuk hukum adat.

D. Pluralisme Dalam Arah Politik Pembangunan Hukum di Indonesia

Dengan dikumandangkannya Proklamasi Kemerdekaan dan setelah diundangkannya UUD 1945 pada 18 Agustus 1945 seharusnya segera berlaku suatu sistem hukum nasional yang utuh guna menghapus semua warisan hukum pemerintahan kolonial Belanda yang ditransplantasikan di Indonesia (Sutandyo Wignjosoebroto. 2002: 258). Hal ini disadari karena hukum-hukum kolonial itu tidak selaras dengan cita-cita proklamasi, juga bersifat menindas dan eksploitatif. Namun pada kenyataannya hukum-hukum itu tetap dipakai sebagai rujukan dan dipertahankan untuk menghindari kekosongan hukum. 
Bersamaan dengan itu perundang-undangan ternyata juga masih mengakui berlakunya hukum adat, dan hukum Islam. Karena itu, politik hukum unifikasi dalam pembaharuan hukum dilaksanakan untuk mendorong kebijakan pembaharuan hukum yang mengarah pada penggantian hukum-hukum warisan kolonial, dan pengkooptasian hukum adat yang sangat beragam serta hukum Islam menjadi hukum positif negara $(\mathrm{H}$. Andi Mattalatta. 2009: 4). Sebagaimana juga dikatakan oleh Satya Arinanto bahwa :

"...permasalahan utama politik pembangunan hukum nasional antara lain adalah sebagai berikut:

memperbarui atau mengganti peraturan hukum dari masa kolonial yang masih berlaku melalui Aturan Peralihan UUD 1945; dan (2) menciptakan hukum baru yang secara utuh bersumber pada Pancasila dan UUD 1945 (termasuk Perubahanperubahannya), sesuai dengan tuntutan dan perkembangan masyarakat pada tingkat lokal, nasional, regional, dan internasional dalam era globalisasi" (Satya Arinanto. 2006: 68-98).

Kenyataannya

dalam

pelaksanaan politik hukum unifikasi tidak sepenuhnya dapat terlaksana. Kekuasaan negara untuk melakukan unifikasi hukum memiliki keterbatasan. Bahkan dalam negara yang menganut sistem politik totaliter sekalipun, tidak begitu saja dapat menghapuskan keanekaragaman hukum yang hidup dan berkembang di wilayah kekuasaannya. Karena selain keterbatasan kemampuan negara tadi, hukum dalam kenyataannya tidak semata-mata "ditemukan" dalam masyarakat seperti yang dipikirkan oleh von Savigny. Hukum hakekatnya adalah aturan atau ketentuan yang merupakan hasil interelasi sistem sosial-politik yang terkait dalam rantai sejarah, nilai-nilai dalam masyarakat, perilaku elit kekuasaan serta pengaruh nilai-nilai dari luar wilayah kekuasaan. Dan pembaharuan hukum adalah politik hukum yang dipengaruhi oleh ketentuan-ketentuan hukum yang telah ada sebelumnya, dan dominasi sistem politik yang menyelimuti. Di mana dari berbagai penilitian yang telah ada dapat disimpulkan adanya tiga tipe hukum yang terkait dengan relasinya dengan politik yaitu hukum represif, hukum otonom dan hukum responsif (Philippe Nonet dan Philip Selznick. 2008: 19).

Meskipun demikian, yang terpenting dalam politik hukum unifikasi perundang-undangan ini adalah bagaimana mengambil sebanyak mungkin nilai-nilai dari pluralisme hukum yang hidup dan berkembang di dalam masyarakat tersebut menjadi hukum positif negara, sehingga hukum yang dilahirkan dapat diterima oleh seluruh warga negara sebagai energi positif dalam mewujudkan cita-cita bangsa. Karenanya, kemungkinan masih adanya pluralisme hukum di masa yang akan datang semata-mata hanya untuk mewadahi kearifan lokal yang memang merupakan kekhasan daerah dan atau etnis tertentu yang justru memberikan keuntungan lebih jika tidak dilaksanakan politik hukum unifikasi secara kaku.

Arah politik pembangunan hukum Indonesia ke depan dapat diuketahui dari Undang-Undang Republik IndonesiaNomor 17 Tahun 2007 Tentang Rencana Pembangunan Jangka Panjang Nasional Tahun 2005-2025. Pada Bab IV Arah, Tahapan, Dan Prioritas Pembangunan Jangka Panjang Tahun 2005-2025 antara lain dinyatakan :

"Terwujudnya Indonesia yang demokratis, berlandaskan hukum dan berkeadilan ditunjukkan oleh hal-hal berikut: 1. Terciptanya supremasi hukum dan penegakkan hak-hak asasi manusia yang bersumber pada Pancasila dan Undang-Undang Dasar Negara Republik Indonesia Tahun 1945 serta tertatanya sistem hukum nasional yang mencerminkan kebenaran, keadilan, akomodatif, dan aspiratif. 
Terciptanya penegakan hukum tanpa memandang kedudukan, pangkat, dan jabatan seseorang demi supremasi hukum dan terciptanya penghormatan pada hak-hak asasi manusia." (Lihat : Undang-Undang Republik IndonesiaNomor 17 Tahun 2007 Tentang Rencana Pembangunan Jangka Panjang Nasional Tahun 2005-2025. Bab IV.1 ARAH PEMBANGUNAN JANGKA PANJANG TAHUN 2005-2025. Sekretariat Negara RI. Halaman 41).

Sementara itu mengenai arah pembangunan jangka panjang tahun 2005-2025, pada huruf E. Reformasi Hukum dan Birokrasi, ditegaskan :

“..........Pembangunan

hukum dilaksanakan melalui pembaruan materi hukum dengan tetap memerhatikan kemajemukan tatanan hukum yang berlaku dan pengaruh globalisasi sebagai upaya untuk meningkatkan kepastian dan perlindungan hukum, penegakan hukum dan hak-hak asasi manusia (HAM), kesadaran hukum, serta pelayanan hukum yang berintikan keadilan dan kebenaran, ketertiban dan kesejahteraan dalam rangka penyelenggaraan negara yang makin tertib, teratur, lancar, serta berdaya saing global."

Dari ketentuan UndangUndang No. 17 Tahun 2007 Tentang Rencana Pembangunan Jangka Panjang Nasional Tahun 2005-2025 dapat disimpulkan bahwa kata kunci dalam arah pembangunan hukum ke depan adalah membangun hukum yang berkeadilan dan memperhatikan kemajemukan hukum. Arah politik pembangunan hukum yang demikian itu mengindikasikan bahwa pluralisme hukum diakui dan akan dikembangkan sebagai landasan sistem hukum nasional yang akan dibangun.
E. Politik Pluralisme Hukum dan Pengakuan Terhadap Hukum Tidak Tertulis Dalam UU No. 48 Tahun 2009 Tentang Kekuasaan Kehakiman

Politik hukum suatu undangundang dapat diketahui antara lain dengan menganalisis kandungan nilai-nilai yang terdapat dalam norma yang ada di dalamnya. Kandungan nilai-nilai politik hukum dalam undang-undang tidak terlepas atau dipengaruhi oleh proses politik dan kekuatan-kekuatan politik yang melingkupinya. Selain itu politik hukum dalam suatu undang-undang dapat pula dipengaruhi oleh konfigurasi ekonomi, sosial, budaya, religi atau ideologi (partai) dan bahkan oleh tekanan negara-negara pemberi pinjaman kepada Indonesia dan politik ekonomi global.

Hampir semua undangundang kekuasan kehakiman yang pernah berlaku memberikan pintu masuk bagi hakim untuk menggali dan mengangkat hukum tidak tertulis (hukum adat) dalam pertimbangan putusan. Melalui ketentuan tersebut putusan hakim akan menjadi hukum positip yang baik dan agar memiliki daya keberlakuan tinggi harus sesuai dengan the living law (Ade Saptomo. 2009: 15-16).

Dalam UU No. 48 Tahun 2009 tentang Kekuasaan Kehakiman tidak dapat ditemukan kata pluralism hukum pada norma yang terkandung dalam pasal-pasal maupun ayatayatnya. Namun demikian, tidak berarti bahwa UU ini tidak menganut atau setidaknya mengakui keberadaan pluralisme hukum, yaitu adanya pengakuan terhadap adanya sistem hukum lain di luar sistem hukum negara. Hal ini sejalan dengan arah politik hukum yang dianut oleh Undang-Undang No. 17 Tahun 2007 Tentang Rencana Pembangunan Jangka Panjang Nasional Tahun 2005-2025, bahwa pembangunan hukum dilaksanakan melalui pembaruan materi hukum dengan tetap memerhatikan kemajemukan tatanan hukum yang berlaku.

Persoalannya adalah, sejauh mana pengakuan terhadap hukum 
tidak tertulis tersebut dan pada norma mana yang mengakui adanya pluralisme (kemajemukan) hukum. Jika dicermati dari seluruh pasal-pasal dalam UU No. 48 Tahun 2009 tentang Kekuasaan Kehakiman terdapat beberapa yang terkait dan mengandung politik hukum yang memberikan pengakuan terhadap keberadaan hukum tidak tertulis. Pasal 2 (2) UU No. 48 Tahun 2009 tentang Kekuasaan Kehakiman dinyatakan "Peradilan negara menerapkan dan menegakkan hukum dan keadilan berdasarkan Pancasila". Dari redaksi pasal ini tidak ada kejelasan hukum apa yang dimaksud, apakah hukum negara (state law), hukum tidak tertulis (non state law) atau kedua-duanya. Namun demikian, karena redaksi pasal ini menegaskan bahwa peradilan yang dimaksud dalam pasal tersebut adalah peradilan negara, maka dapat disimpulkan bawa hukum yang diterapkan dan ditegakkan oleh kekuasaan kehakiman adalah hukum negara (state law), sehingga pasal ini mengesankan bahwa UU No. 48 Tahun 2009 tentang Kekuasaan Kehakiman menganut politik sentralisme hukum dan tidak mengakui keberlakukan hukum tidak tertulis (non state law). Sayangnya, Penjelasan Pasal 2 Ayat (2) menyatakan "Cukup jelas", sehingga pendirian yang terakhir ini seolah menjadi semakin mendapat penegasan.

Selanjutnya dalam Pasal 4 (1) UU No. 48 Tahun 2009 tentang Kekuasaan Kehakiman menyatakan "Pengadilan mengadili menurut hukum dengan tidak membedabedakan orang”. Sebagaimana Pasal 2 ayat (2) di atas, dalam pasal ini juga tidak ada kejelasan hukum apakah yang dimaksud, dan jika dibaca dalam Penjelasan Pasal 4 hanya dikatakan "Cukup jelas". Sampai di sini tampaknya politik hukum yang dianut oleh UU No 48 Tahun 2009 tentang Kekuasaan Kehakiman mengikuti faham sentralisme hukum yaitu hanya hukum tertulis, atau hukum positip dalam perundang-undangan yang diterapkan dan ditegakkan.
Pasal 5 (1) UU No. 48 Tahun 2009 tentang Kekuasaan Kehakiman menyatakan "Hakim dan hakim konstitusi wajib menggali, mengikuti, dan memahami nilai-nilai hukum dan rasa keadilan yang hidup dalam masyarakat". Ketentuan pasal ini mulai membuka peluang bagi penerapan dan penegakan hukum tidak tertulis oleh badan-badan peradilan sebagai pelaksana kekuasaan kehakiman. Redaksi yang menyatakan hakim wajib menggali, mengikuti dan memahami nilai-nilai hukum dan rasa keadilan yang hidup dalam masyarakat mengandung makna yaitu nilai-nilai hukum dan rasa keadilan yang tidak terdapat dalam hukum tertulis dalam undangundang tetapi ada dan hidup dalam dunia empiris yaitu masyarakat. Meminjam istilah yang digunakan oleh Erlich, nilai-nilai hukum dan rasa keadilan yang hidup dimasyarakat adalah apa yang disebut living law (Sutandyo Wignjosoebroto. 2006: 4). Perintah pasal ini dapat diartikan bahwa selain hakim menerapkan dan menegakkan hukum negara tetapi juga diwajibkan untuk menggali, mengikuti dan memahami nilai-nilai hukum yang hidup dalam masyarakat di luar hukum negara. Dari makna pasal ini dapat disimpulkan bahwa UU No. 48 tahun 2009 tentang Kekuasaan Kehakiman mengakui keberadaan dan keberlakukan non state law di samping hukum negara (state law). Pasal 5 ayat 1 tersebut mendapat menegasan dalam Penjelasan Pasal 5 Ayat (1) yang menyatakan "Ketentuan ini dimaksudkan agar putusan hakim dan hakim konstitusi sesuai dengan hukum dan rasa keadilan masyarakat". Penjelasan pasal ini lebih tegas mengatakan dengan frasa "hukum dan rasa keadilan masyarakat", jadi bukan hanya nilainilai-nya yang harus menjadi acuan dalam setiap putusan hakim tetapi adalah hukum (norma) dan rasa keadilan masyarakat. Dari pemikiran ini maka dapat dikatakan bahwa UU No. 48 Tahun 2009 menganut politik pluralism hukum, setidaknya mengakui keberadaan hukum tidak 
tertulis selain hukum negara yang selalu bersifat tertulis.

Pasal 10 (1) UU No.48

Tahun 2009 tentang Kekuasaan

Kehakiman menyatakan "Pengadilan dilarang menolak untuk memeriksa, mengadili, dan memutus suatu perkara yang diajukan dengan dalih bahwa hukum tidak ada atau kurang jelas, melainkan wajib untuk memeriksa dan mengadilinya". Sementara itu dalam Penjelasan Pasal 10 dinyatakan "Cukup jelas". Ketentuan pasal ini mengandung arti bahwa pengadilan (melalui hakim) tidak boleh menolak memeriksa, mengadili dan memutus perkara sekalipun hukum negara yang ada dalam perundang-undangan tidak ada (tidak mengatur) atau kurang jelas (mengatur). Artinya, hakim wajib mencari dan menemukan hukum tidak tertulis di luar undang-undang (non state law) untuk memeriksa, mengadili dan memutus perkara yang tidak ada atau kurang jelas aturannya dalam hukum negara. Ketentuan pasal 10 (1) UU No. 48 Tahun 2009 tentang Kekuasaan Kehakiman ini juga mengandung politik pluralism hukum yaitu adanya pengakuan terhadap hukum tidak tertulis di samping hukum tertulis.

Pasal 50 (1) UU N0. 48

Tahun 2009 tentang Kekuasaan Kehakiman menyatakan "Putusan pengadilan selain harus memuat alasan dan dasar putusan, juga memuat pasal tertentu dari peraturan perundang-undangan yang bersangkutan atau sumber hukum tak tertulis yang dijadikan dasar untuk mengadili". Selanjutnya Penjelasan Pasal 50 menyebutkan "Cukup jelas". Ketentuan pasal ini menegaskan ketentuan pasal sebelumnya bahwa pengadilan setelah hakim menggali, mengikuti dan memahami rasa keadilan yang hidup dalam masyarakat dan mencari dan menemukan hukum tidak tertulis di luar undang-undang (non state law) untuk memeriksa, mengadili dan memutus perkara yang tidak ada atau kurang jelas aturannya dalam hukum negara, maka hasilnya dituangkan sebagai alasan dan dasar putusan.
Pasal 50 (1) UU N0. 48 Tahun 2009 tentang Kekuasaan Kehakiman merupakan klimaks dari pengakuan terhadap keberadaan hukum tidak tertulis di luar hukum negara yang tertulis. Dapat dikatakan bahwa pasal ini merupakan puncak dari politik pluralism hukum yang dianut oleh UU No. 48 Tahun 2009 tentang Kekuasaan Kehakiman.

Dari analisis pasal-pasal di atas, dapat disimpulkan bahwa sekalipun UU No. 48 Tahun 2009 tentang Kekuasaan Kehakiman menganut politik pluralism hukum dan mengakui keberadaan dan keberlakuan hukum tidak tertulis, namun politik pluralism hukum yang digunakan masih semu, yang berakibat bahwa sesungguhnya dominasi hukum negara masih terjadi dan hukum tidak tertulis hanya menjadi pelengkap terhadap hukum negara. Konsekuensinya, jika terhadap suatu perkara sudah diatur oleh hukum negara maka hukum tidak tertulis harus dikesampingkan sekalipun hukum negara itu tidak memberikan rasa keadilan kepada masyarakat. Hukum tidak terulis (hukum adat) hanya boleh diberlakukan manakala hukum negara tidak memberi pengaturan sama sekali. Manakala tidak ada kesepahaman antara hukum adat denagn hukum positif milik negara, negara sebagai pemangku kekuasaan merasa berhak melakukan pemaksaan terhadap dihormatinya hukum positip milik negara sehingga segala persoalan dan perselisihan yang terjadi di dalam wilayah negara RI mau tidak mau harus diselesaikan dengan menggunakan hukum positip milik negara (Anonim. 2009:32).

F. Politik Pluralisme Hukum dan Pengakuan Terhadap Hukum Tidak Tertulis Dalam Undang-Undang Kekuasaan Kehakiman Di Masa Datang

Politik pluralisme hukum dalam undang-undang kekuasaan kehakiman di masa datang sangat terkait dengan konsep negara hukum yang dianut oleh Indonesia. Pada 
awalnya konsep negara hukum sangat lekat dengan tradisi politik negaranegara barat yaitu freedom under the rule of law. Karena itu menurut Tamanaha, liberalisme yang lahir pada akhir abad ketujuh belas awal abad kedelapan belas menempati ruang yang sangat esensial bagi konsep negara hukum dan negara hukum pada masa kini secara keseluruhan dipahami dalam istilah leberalisme, Tamanaha menulis “...every version of liberalism reserve and essential place for the rule of law, and the rule of law today is thoroughly understood in the terms of liberalism." Akan tetapi di atas segala-galanya dari liberalisme dalam tradisi politik barat adalah kebebasan individu, seperti dalam terminologi klasik yang dikemukan oleh John Stuart Mill “...the only freedom which divers the name, is that of pursuing our own good in our own way, so long as we do not attempt to deprive others of theirs or impede their efforts to obtain it." (Hamdan Zoelva. 2009: 46). Ide mengenai negara dalam suatu tatanan hukum yang adil terus menerus berkembang di Eropa dari abad ke-16 hingga permulaan abad ke-20. Dalam dekade waktu itu terjadi perkembangan pemikiran mengenai konsep negara; dari negara hukum klasik (pengertian negara dalam arti sempit) sampai dengan negara hukum formal.

Dalam khasanah ilmu hukum Indonesia terdapat dua istilah yang diterjemahkan sama ke dalam Bahasa Indonesia menjadi "negara hukum" yaitu rechtsstaat dan the rule of law. The Rule of Law dalam literaturliteratur terkemuka memiliki pengertian yang sama dengan Negara Hukum. Demikian juga dalam kepustakaan Indonesia istilah Negara Hukum merupakan penterjemahan langsung dari Rechtstaat. Pernyataan ini dikuatkan pendapat para pakar pakar hukum di Indonesia, diantaranya adalah Notohamidjojo dan Sumrah, yang mengatakan :

"Dengan timbulnya gagasangagasan pokok yang dirumuskan dalam konstitusi-konstitusi dari abad IX itu, maka timbul juga istilah Negara hukum (rechstaat). Yang sudah kita kenal lama adalah pengertian Rechstaat atau negara hukum atau menjamin kata-kata dalam Penjelasan UndangUndang Dasar 1945, negara yang berdasarkan atas hukum." (O. Notohamidjojo. 1970: 31).

Begitu juga dengan apa yang dinamakan rule of law memiliki pengertian yang sama dengan negara hukum. Hal ini dikemukakan oleh Sunaryati Hartono sebagaimana yang dikutip Azhary, bahwa agar supaya tercipta suatu Negara Hukum yang membawa keadilan bagi seluruh rakyat yang bersangkutan, penegakan the rule of law itu harus diartikan dalam arti yang materiil (Azhary.1995: 31). Menurut Sudargo Gautama sebagaimana dikutip Teguh Presetyo, ada persamaan utuh antara Rule of Law dengan Negara Hukum, sebagaimana dinyatakan :

"... dan jika berbuat demikian, maka pertamatama kita melihat bahwa dalam suatu negara hukum, terdapat pembatasan kekuasaan negara terhadap perseorangan. Negara tidak maha kuasa, tidak bertindak sewenang-wenang.

Tindakan-tindakan negara terhadap warganya dibatasi oleh hukum. Inilah yang oleh ahli hukum Inggris dikenal dengan Rule of Law" (Teguh Prasetyo. 2010: 132).

Pendapat dari sisi yang berbeda dikemukakan oleh Moch. Kusnardi, yang menyatakan, lain daripada negara Eropa Barat, di Inggris sebutan Negara Hukum (rechsstaat) adalah the rule of law, sedangkan di Amerika Serikat diucapkan sebagai government of law, but not of man (Moch. Kusnardi dan Harmaily Ibrahim. 1976: 79). Hadjon bertolak belakang dengan pendapat para ahli hukum tersebut. Hadjon mengemukakan konsep berdasarkan 
latar belakang sistem hukum yang menjadi sandaran istilah tersebut, sebagaimana dinyatakan (Philipus M. Hadjon. 1987: 72) :

"Konsep rechtstaat lahir dari suatu perjuangan menentang absolustisme, sehingga sifatnya revolusioner, sebaliknya konsep the rule of law berkembang secara evolusioner. Hal ini nampak dari isi atau kriteria rechtstaat dan kriteria the rule of law. Konsep rechtstaat dan kriteria the rule of law. Konsep rechtstaat bertumpu atas sistem hukum kontinental yang disebut civil law, modern roman law, sedangkan konsep the rule of law, bertumpu atas sistem hukum yang disebut common law".

Sekalipun terjemahan dalam Bahasa Indonesia sama tetapi kedua istilah tersebut sebenarnya memiliki perbedaaan sebagaimana diidentifikasi oleh Roscoe Pound. Rechtsstaat memiliki karakter administratif sedangkan the rule of law berkarakter judicial (Roscoe Pound. 1957: 7).

Rechtsstaat bersumber dari tradisi hukum negara-negara Eropah Kontinental yang bersandar pada civil law dan legisme yang menganggap hukum adalah hukum tertulis atau undang-undang. Kebenaran hukum dan keadilan di dalam Rechtsstaat terletak pada pada ketentuan bahkan pembuktian tertulis. Hakim yang baik menurut paham civil law (legisme) di dalam rechtsstaat adalah hakim yang dapat menerapkan atau membuat putusan sesuai dengan bunyi undangundang. Pilihan pada hukum tertulis dan paham legisme di rechtsstaat karena menekankan kepastian hukum. Sedangkan the rule of law berkembang dalam tradisi hukum negara-negara anglo saxon yang mengembangkan common law (hukum tak tertulis).
Kebenaran hukum dan keadilan di dalam the rule of law bukan semata-mata hukum tertulis, bahkan di sini hakim dituntut untuk membuat hukump-hukum sendiri melalui yurisprudensi tanpa harus terikat secara ketat kepada hukum tertulis. Putusan hakimlah yang lebih dianggap hukum yang sesuangguhnya daripada hukum tertulis. Hakim diberi kebebasan untuk menggali nilai-nilai keadilan dan membuat keputusan sesuai dengan rasa keadilan yang digalinya dari masyarakat. Hakim yang baik di sini adalah hakim yang dapat membuat keputusan berdasar nilai keadilan yang keadilan masyarakat. Pemberian keleluasaan bagi hakim untuk tidak terlalu terikat pada hukum tertulis di sini karena penegakan hukum ditekankan pada pemenuhan rasa keadilan bukan pada hukum-hukum formal.

Pendapat yang sama dikemukakan oleh Philipus M. Hadjon yang menyatakan (Philipus M. Hadjon, 1987: 72) :

"Di dalam catatan sejarah diungkapkan bahwa konsep negara hukum dapat dibedakan menurut konsep Eropa Kontinental yang basa dikenal dengan Rechstaat dan dalam konsep Anglo Saxon dikenal dengan Rechstaat dan dalam konsep Anglo Saxon dikenal dengan Rule of Law. Dengan demikian dapat dikatakan bahwa Rechstaat tersebut direduksi dalam sistem hukum yang dinamakan Civil Law atau yang biasa kita sebut dengan Modern Roman Law. Konsep Rechtstaat ini ditelaah secara historis merupakan penentangan secara tajam atas pemikiran kaum Hegelianisme yang mengembangkan

absolutisme, jadi dapat dikatakan sebagai revolusioner. Berbeda dengan Rule of Law yang berkembang dengan metode evolusioner, yang direduksi 
dalam sistem hukum Common Law."

Negara hukum Indonesia yang berdasar Pancasila dan UUD 1945 mengambil konsep prismatik atau integratif dari dua konsep tersebut sehingga prinsip kepastian hukum dan rechsstaat dipadukan dengan prinsip keadilan dalam the rule of law. Indonesia tidak memilih salah satunya tetapi memasukkan unsur-unsur dari keduanya, sehingga dapat dikatakan Indonesia menganut konsep negara hukum prismatic. Menurut F.W. Riggs (1964: 126-132), masyarakat prismatik (prismatic society) adalah kesatuan masyarakat yang dibangun diantara dua kepentingan. Konsep negara hukum prismatik menjadi keniscayaan dikarenakan (Moh. Mahfud MD. 2006: 14):

"Pada saat ini sudah sulit menarik perbedaan yang substantif antara rehcttstaat dan the rule of law. Kepastian hukum harus ditegakkan untuk memastikan bahwa keadilan di dalam masyarakat juga tegak. Dalam praktek perpaduan ini kemudian seringkali menimbulkan ekses komplikatif dimana konsep yang semula dimaksudkan sebagai integrasi dari keduanya ternyata dipilih-pilih salah satunya sebagai alternatif yang lebih menguntungkan dalam kasus konskrit baik oleh penegak hukum maupun oleh justiciabelen.

Setelah empat kali amandemen UUD 1945 pada saat ini tidak lagi tercantum istilah rehctsstaat secara eksplisit. Ini semakin menegaskan tentang konsep negara hukum prismatik tersebut. Istilah rechtstaat semula tercantum di dalam Penejelasan UUD 1945 pada Bagian Umum, Sub Bagian Sistem Pemerintahan Negara, menyebutkan istilah rechtsstaat sampai dua kali yakni Angka I yang berbunyi
"Indonesia ialah negara yang berdasar atas hukum (rechtsstaat)", dan Angka I butir I yang berbunyi "Negara Indonesia berdasar atas hukum (rechtsstaat), tidak berdasar kekuasaan belaka (machtsstaat). Namun setelah MPR menyepakati bahwa dalam melakukan amandemaen Penjelasan ditiadakan dari UUD 1945 dan isinya yang bersifat normatif dimasukkan di dalam pasal-pasal maka istilah rechtsstaat ditiadakan. Pada amandemen ke tiga UUD 1945 (tahun 2001) prinsip negara hukum kemudian dicantumkan di dalam Pasal 1 ayat (3) dengan istilah yang netral (tanpa menyebut rechtsstaat atau the rule of law).

Dengan latar belakang seperti diuraikan di atas sebenarnya tidak ada alasan bagi UU No. 48 Tahun 2009 tentang Kekuasaan Kehakiman untuk ragu-ragu dalam menganut politik pluralism hukum karena Indonesia menganut konsep negara hukum prismatik. Ketegasan dalam menganut politik pluralisme hukum harus ditegaskan melalui keberpihakan terhadap pluralisme yang kuat dan bukan pluralisme yang lemah. Jika UU UU No. 48 Tahun 2009 tentang Kekuasaan Kehakiman menganut paham pluralism yang lemah, sesungguhnya yang terjadi tetaplah sentralisme hukum. Sebagaimana dikatakan oleh I Nyoman Nurjaya 2007 : 18) : "Pluralisme yang lemah sesungguhnya merupakan bentuk lain dari sentralisme hukum (legal centralism), karena walaupun dalam kenyataannya hukum negara (state law) mengakui adanya sistem-sistem hukum lain dalam masyarakat, tetapi hukum negara tetap dipandang sebagai superior atau super-ordinasi, dan sementara itu sistem-sistem hukum yang lain bersifat inferior atau sub-ordinasi dalam hierarki sistem hukum negara. Ilustrasi dari weak legal pluralism adalah konsep pluralism hukum 


\begin{abstract}
dalam konteks interaksi antara sistem mhukum pemerintah kolonial dengan sistem hukum rakyat (folk law) dan hukum agama (religius law) yang berlangsung di negeri-negeri jajahan".
\end{abstract}

Senada dengan itu, sebagai konsekuensinya terjadi kondisi seperti yang dikatakan Anne Griffiths bahwa sentralisme hukum menempatkan hukum negara berada di atas kaidah hukum lainnya, seperti hukum adat, hukum agama, maupun kebiasankebiasaan. Kaidah-kaidah hukum lain tersebut dianggap memiliki daya ikat yang lebih lemah dan harus tunduk pada hukum negara (Anne Griffiths, 2005: 71).

\section{G. Penutup}

Dari pembahasan yang telah diuraikan di atas dapat disimpulkan hal-hal sebagai berikut.

a) UU No. 48 Tahun 2009 tentang Kekuasaan Kehakiman menganut politik pluralism hukum dan mengakui keberadaan dan keberlakuan hukum tidak tertulis, namun politik pluralism hukum yang digunakan masih semu (weak legal pluralism), yang berakibat bahwa sesungguhnya dominasi hukum negara masih terjadi dan hukum tidak tertulis hanya menjadi pelengkap terhadap hukum negara.

b) $\mathrm{Ke}$ depan politik pluralisme hukum dalam UU Kekuasaan Kehakiman idealnya tidak dibuat bersyarat yaitu hukum tidak tertulis hanya boleh diterapkan dan digunakan sebagai dasar putusan jika hukum negara tidak mengatur. Seharusnya politik pluralism menganut apa yang disebut strong legal pluralism. Sehingga kemajemukan tatanan hukum dalam masyarakat (hukum negara dan hukum tidak tertulis) dipandang sama kedudukannya.

\section{H. Saran}

Perlu dilakukan rekonstruksi terhadap politik pluralism yang dianut oleh UU No. 48 Tahun 2009 tentang Kekuasaan Kehakiman agar kemajemukan hukum dapat benarbenar dapat terakomodasi dalam sistem hukum di Indonesia. 


\section{Daftar Pustaka}

Abdul Hakim Garuda Nusantara. 1985. "Politik Hukum Nasional". Makalah Karya Latihan Bantuan Hukum, YLBHI dan LBH Surabaya. September 1985.

Abdurrahman. 2006. "Peranan Hukum Adat Dalam Aplikasi Kehidupanberbangsa Dan Bernegara". Makalah Seminar Arah Pembangunan Hukum Menurut UUD 1945 Hasil Amandemen. Jakarta 29-31 Mei 2006. BPHN. Departemen Hukum Dan HAM RI.

Ade Saptomo. 2009. Revitalisasi Hukum Adat Nusantara Ke Dalam Pengembangan Ilmu Hukum dan Pembangunan Hukum Nasional. Makalah Rapat Senat Terbuka Dalam Rangka Dies Natalis ke 63 Fakultas Hukum Universitas Gadjah Mada. Yogyakarta. 17 Pebruari 2009.

Adi Sulistiyono, 2004. "Kematian Positivisme Dalam Ilmu Hukum ?”. Jurnal Newsletter No. 59 Desember 2004. Yayasan Pusat Pengkajian Hukum. Jakarta.

Amzulian Rifai, et.all. 2010. Wajah Hakim Dalam Putusan Studi Atas Putusan Hakim Berdimensi HAM. PUSHAM UII, Norwegian Center for Human Rights, Komisi Yudisial RI.

Anne Griffiths. 2005. "Law in a Transnational World : Legal Pluralism Revisited”. The First Asian Initiative Meeting. School of Industrial Fisheries and School of Legal Studies. Cochin University of Science and Technology. Kochi. Keralaya:

Anonim. 2009. "Laporan Khusus :Hukum Adat di Persimpangan Jalan”. Buletin Komisi Yudisial. Vol. IV No. 1 Agustus 2009.

Antony Allott. 1980. The Limit of Law. London. Butterworths.

Azhary. 1995. Negara Hukum Indonesia - Analisis Yuridis Normatif Tentang Unsur-Unsurnya. UI Press. Jakarta.

Benda-Beckmann F, K. Benda-Beckmann and Anne Griffiths. 2005. Mobile People Mobile Law. Expanding Legal Relations in a Colntracting Worl. Ashgate. USA.

Bernadinus Steni. 2008. "Transplantasi Hukum, Posisi Hukum Lokal dan Persoalan Agraria”. http://my.opera.com/bernads/blog/transplantasi-hukum-posisi-hukum-lokal-danpersoalan-agraria.

Bradford W. Morse. 1987 "Indigenous law and state legal system : conflict and compatibility", dalam Indigenous Law and the State, Bradford W. Morse \& Gordon R. Woodman (eds).

C.F.G. Sunaryati Hartono. 1991. Politik Hukum, Menuju Suatu Sistem Hukum Nasional. Alumni. Bandung.

C. Maya Indah S. "Refleksi Atas Paradigma Positivisme Dalam Ilmu Hukum Menuju Keadilan”. Jurnal Refleksi Hukum. Edisi Oktober 2010. FH UKSW.

Esmi Warassih. 2005. Pranata Hukum, Sebuah Telaah Sosiologis. Suryandaru Utama. Semarang.

F.W. Riggs. 1964. Administration in Developing Countries : The Theory of Prismatic Society. Houghton Miflin Company. Boston.

H. Andi Mattalatta. 2009. Politik Hukum Perundang-Undangan. http://www.djpp.info/htndam-puu/64-politik-hukum-perudang-undangan.html.

Hamdan Zoelva. 2009. " Negara Hukum Dalam Perspektif Pancasila”. Jurnal Negarawan. ISSN 1907-6991. Sekretariat Negara RI. 
H.R. Otje Salman dan Anton F. Susanto. 2004. Teori Hukum (Mengingat, Mengumpulkan dan Membuka Kembali). PT. Refika Aditama. Bandung.

I Nyoman Nurjaya. 2007. Reorientasi Paradigma Pembangunan Hukum Negara Dalam masyarakat Multikultural : Perspektif Antropologi Hukum. Pidato Pengukuhan Jabatan Guru Besar Dalam Bidang Ilmu Hukum Pada Fakultas Hukum Universitas Brawijaya. Malang.

2008. "Potensi dan Kedudukan Hukum Adat dalam Politik Pembangunan Hukum Nasional “. Makalah Seminar Hukum Adat dalam Politik Hukum Nasional, diselenggarakan oleh Fakultas Hukum Universitas Airlangga pada tanggal 20 Agustus 2008 di Fakultas Hukum Universitas Airlangga.

Iman Sudiyat. 1991. Asas-Asas Hukum Adat, Bekal Pengantar. Liberty. Jogyakarta.

Jimly Asshiddiqie. 2003. Konsolidasi Naskah UUD 1945. Penerbit Yarsif Watampone. Jakarta.

John Stanton. 2006. The Limit of Law. Stanford Encyclopaedia of Philosophy.

Kurnia Warman. 2009. Kedudukan Hukum Adat Dalam Realitas Pembangunan Hukum Agraria Indonesia. Jurnal Konstitusi Volume 6 Nomor 4 Nopember 2009.

M. Saihu. Tanpa Tahun. "Independesi dan Akuntabilitas Kekuasaan Kehakiman" (Online).(http://www.komisihukum.go.id/index.php?option $=$ com_content\&view $=$ article $\& i$ $d=3 \% 3$ Aindependesi-dan-akuntabilitas-kekuasaan-kehakiman\&catid=1\%3Alatest news\&Itemid=50\&lang=in, 21/7/2010).

Mahadi. 1991. Uraian Singfkat Tentang Hukum Adat Sejak RR-Tahun 1854. Alumni. Bandung.

Marc Galanter. 1981. "Justice in Many Rooms" dalam Access to Justice and the Walfare State". Mauro Cappelletti (ed). -1981. “Law In Many Rooms”, Journal of Legal Pluralism, Th. 1981. No. 9.

Moh. Mahfud MD. 2006. "Politik Hukum Menuju Pembangunan Sistem Hukum Nasional". Makalah Seminar Atah Pembangunan Hukum Menurut UUD 1945 Hasil Amandemen. BPHN Departemen Hukum dan HAM RI, 29-31 Mei 2006.

2010. Mengawal Arah Politik Hukum : Dari Prolegnas Sampai Judicial Review. MK RI, 20 Pebruari 2010.

2010a. "Mengawal Arah Politik Hukum nasional Melalui Prolegnas dan Judicial Review”. Buletin Komisi Yudisial. Vol. IV No. 4 Februari - Maret 2010.

Moch. Kusnardi dan Harmaily Ubrahim. 1976. Pengatar Hukum Tata Negara Indonesia. Pusat Studi HTN. UI. Jakarta.

O. Notohamidjojo. 1970. Makna Negara Hukum. Badan Penerbit Kristen. Jakarta.

Philipus M. Hadjon. 1987. Perlindungan Hukum Bagi Rakyat Indoesia. Bina Ilmu. Surabaya.

Padmo Wahyono. 1986. Indonesia Negara Berdasarkan Atas Hukum. Cetakan II. Ghalia Indonesia. Jakarta.

1991. "Menyelisik Proses Terbentuknya Peraturan Perundang-Undangan”. Majalah Forum Keadilan No. 29 April 1991.

Philippe Nonet dan Philip Selznick. 2008. Hukum Responsif (terjemahan). Nusamedia. Bandung.

Richard A. Posner. 2010. How Judges Think. Harvard University Press. Massachusetts. 
Roger Cotterrel. 2006. Law, Culture and Society Legal Ideas in The Mirror of Social Theory. Ashgate. Hampshire England.

Roscoe Pound. 1957. The Development of Constitution Guarantee of Liberty. Yale University Press. New Haven. London.

Satjipto Raharjo, 1991. Ilmu Hukum. Cetakan III, Citra Aditya Bhakti. Bandung,

1995. "Hubungan Hukum Adat Dan Hukum Nasional Dalam Pembangunan Nasional". Simposium Tentang Integrasi Hukum Adat Ke Dalam Hukum Nasional Selama 50 Tahun Terakhir. Diselenggarakan Oleh Badan Pembinaan Hukum Nasional Departemen Kehakiman Jakarta, 09 - 10 Januari 1995.

-, 1995. "Hubungan Hukum Adat Dan Hukum Nasional Dalam Pembangunan Nasional", Makalah Simposium Tentang Integrasi Hukum Adat Ke Dalam Hukum Nasional Selama 50 Tahun Terakhir, Diselenggarakan Oleh : Badan Pembinaan Hukum Nasional Departemen Kehakiman Jakarta, 09 - 10 Januari 1995.

1999. "Masalah Kebhinekaan Sosial Budaya Dalam Reformasi Hukum Nasional Menuju Masyarakat Madani”. Makalah Seminar Hukum Nasional BPHN : Jakarta.

2000. "Mengajarkan Keteraturan Menemukan Ketidakteraturan (Teaching Order Finding Disorder) Tigapuluh Tahun Perjalanan Intelektual dari Bojong ke Pleburan". Pidato Mengakhiri Masa Jabatan Sebagai Guru Besar Tetap Pada Fakultas Hukum Universitas Diponegoro. 15 Desember 2000.

2003. Sisi-sisi Lain Dari Hukum Di Indonesia. Jakarta. PB. Kompas.

2010. “Di Luar Pengadilan”. Surat Kabar Kompas. 15 Januari 2010.

Satya Arinanto. 2006. Jurnal Konstitusi vol. 3 no. 3 (Sep. 2006), Mahkamah Konstitusi RI.

Soedarto, 1986. Hukum dan Hukum Pidana. Alumni. Bandung.

1986. Pengantar Penelitian Hukum. UI Press. Jakarta.

Sutandyo Wignjosoebroto.2002. Hukum Paradigma, Metode dan Dinamika Masalahnya. ELSAM dan HuMa. Jakarta.

2006. "Masalah Pluralisme Dalam Pemikiran Dan Kebijakan Perkembangan Hukum Nasional". Makalah Seminar Nasional Pluralisme Hukum : Perkembangan di Beberapa Negara, Sejarah Pemikirannya di Indonesia dan Pergulatannya Dalam Gerakan Pembaharuan Hukum. 21 November 2006 Universitas Al Azhar, Jakarta.

2008. Hukum Dalam Masyarakat : Perkembangan dan Masalah. Bayumedia. Malang.

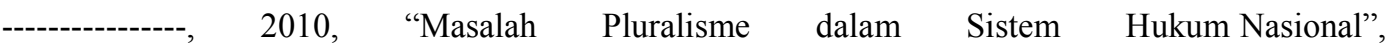
http://soetandyo.wordpress.com/2010/08/19/masalah-pluralisme-dalam-sistem-hukumnasional/. 12/8/2011

Sulistyowati Irianto. 2007 "Pluralisme Hukum Dalam Perspektif Global". Jurnal Law, Society \& Development. Vol. 1. No. 3. Agustus 2007.

2009. Hukum Yang Bergerak. Yayasan Obor Indonesia. Jakarta.

2009. Metode Penelitian Hukum Konstelasi dan Refleksi. Yayaysan Obor. Jakarta.

Teguh Prasetyo. 2010. "Rule Of Law Dalam Dimensi Negara Hukum Indonesia". Jurnal Releksi Hukum. Edisi Oktober 2010. 
Theo Huijbers. 1982. Filsafat hukum Dalam Lintasan Sejarah. Kanisius Jogyakarta.

Wartheim WF. 1999. Masyarakat Indonesia dalam Transisi Studi Perubahan Sosial. PT. Tiara Wacana. Yogyakarta.

Widodo Dwi Putro. 2009. "Mengkritisi Positivisme Hukum, : Langkah Awal Memasuki Diskursus Metodologis Dalam Penelitian Hukum". Metode Penelitian Hukum Konsteleasi dan Refleksi. Yayasan Obor Indonesia. Jakarta.

Yanis Maladi. 2010. "Eksistensi Hukum Adat Dalam Konsitusi Negara Pascaamandemen”. Jurnal Mimbar Hukum. Volume 22 Nomor 3 Oktober 2010. 